International Journal of Business Economics (IJBE)

Vol, 1 Issue 2, pp 117-127, March 2020

http://jurnal.umsu.ac.id/index.php/ijbe

eISSN 2686-472X

ORIGINAL ARTICLE

\title{
Effect of Corporate Fundamental and Macro Economic Factors on Share Prices in Indonesia Stock Exchange Market
}

\author{
Mulyanto*, Riyanti
}

\begin{abstract}
This paper aims to examine and analyze the influence of fundamental and macroeconomic factors on stock prices either partially or simultaneously. The research subjects focused on LQ45 Index companies listed on the Indonesia Stock Exchange. Secondary data of Indonesian stock market share prices covering between 2013-2019 were used. One Least Square was used to analyse the data. The sampling technique used is the purposive sampling method, the sample used is the LQ45 Index Company. The results shows fundamental factors include ROA, ROE, DER, EPS, and PER have a positive and significant effect on stock prices. and Inflation and interest rates have a negative and significant effect on stock prices. And simultaneously these variables have a significant and significant effect on stock prices. The study can provide a picture that stock price movements have a strong and clear influence on the company's fundamentals and are reflected in some of the ratios contained in the financial statements, as well as macroeconomic conditions.
\end{abstract}

Keywords: Corporate fundamental, macro economic factors, Stock prices

DOI : https://doi.org/10.30596/ijbe.v1i2.4461

JEL Classification: G00, G14

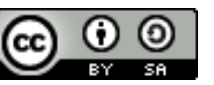

Published by International Journal of Business Economics (IJBE), Indonesia | Copyright (C) 2020 by the Author(s) | This is an open access article distributed under the Creative Commons Attribution License http://creativecommons.org/licenses/by/4.0), which permitsunrestricted use, distribution, and reproduction in any medium, provided the original work is properly cited.

Cite this article as:

Mulyanto., \& Riyanti. (2020). Effect of Corporate Fundamental and Macro Economic Factors on Share Prices in Indonesia Stock Exchange Market. International Journal of Business Economics (IJBE), 1(2), 117-127.

Faculty of Economic and Business, Universitas Muhammadiyah Jakarta

Jl. K.H. Ahmad Dahlan, Cireundeu, Kec. Ciputat Timur, Kota Tangerang

Selatan, Banten 15419, Indonesia

*Corresponding Author: mulyanto.my88@gmail.com 


\section{International Journal of Business Economics (IJBE)}

Vol, 1 Issue 2, pp 117-127, March 2020

http:/ /jurnal.umsu.ac.id/index.php/ijbe

eISSN 2686-472X

\section{INTRODUCTION}

For large-scale companies, the capital market is a medium that can be used as an intermediary in collecting funding from both outside and the country, where there is an allocation of parties who have excess funds to those who need funds. The better performance of the capital market in Indonesia can create opportunities that great for domestic or foreign investors to invest, especially stocks. For investors in the capital market in Indonesia can be called an investment paradise, both local and foreign investment. This is because Indonesia is the most potential market in the Asian region, wherein 2018 investment development in Indonesia is increasing. The number of companies or listed companies listed on the Indonesia Stock Exchange. shows conditions with an increasing trend. The number of companies listed in 2017 was 562 companies. then in 2018, it increased to 619 companies, in 2019 there were 688 listed on the Indonesian stock exchange.

In the Indonesian capital market, the LQ45 stock index is an index in measuring the price performance of a total of 45 shares of companies that have a high level of liquidity and large market capitalization and is also supported by good corporate fundamentals. The LQ45 index is the index that best describes the condition of the stock index in the Indonesian Composite Index, this is illustrated in a chart of stock price developments with fluctuations in the direction of chart patterns.

Factors that cause stock prices to fluctuate, there are 2 (two) first factors in the company (internal factors), namely (1) the company's fundamental factors, (2) corporate actions such as expansion, rights issues, mergers, acquisitions, etc., (3) Analysis projects the company's performance in future. and the next is external factors (from outside), namely (1), the country's macroeconomic fundamentals (2) exchange rate fluctuations against foreign currencies (3) government monetary policy (4) financial factors and (5), market manipulation factors.

Fundamental factors, each taken from several corporate financial ratios which are a measure of the company's financial health, the company's financial ratios studied include profitability ratios namely Return On Asse and Return On Equity, leverage ratios namely Debt to Equity Ratio, growth ratios namely Earning Per Share and Price Earning Ratio valuation ratios. The company's external factors are the macroeconomic aspects examined in this study, namely inflation and interest rates.

The fundamental factors are influential and determine the intrinsic value of shares. The purpose of fundamental analysis is to determine whether the value of a stock is in an overvalued or undervalued condition. A stock is called overvalued if the stock price in the capital market is higher than the fair price, and vice versa.

Macroeconomic factors such as government announcements such as changes in deposit rates, inflation, foreign exchange rates, as well as various regulations and policy regulations and economic deregulation issued by the government, domestic political conditions, and exchange rate volatility are factors that have an influence significant to the movement of stock prices on a country's stock exchange.

\section{METHODS}

The research method used in this research is descriptive verification method. where the descriptive method is used to determine the value of variables individually or independently, one variable or more, without making a comparison or linking one variable to another variable. This type of research is explanatory research. Verification or validation methods are used to determine the causal relationship between variables. Based on the research objectives 


\section{International Journal of Business Economics (IJBE)}

Vol, 1 Issue 2, pp 117-127, March 2020

http://jurnal.umsu.ac.id/index.php/ijbe

eISSN 2686-472X

that have been mentioned is to study and analyze whether the influence of fundamental and macroeconomic factors on stock prices. Data collection by viewing and studying data and written documents in the form of company financial statements and stock data. Interest Rates, Inflation Rates at the Central Statistics Agency .

This study was conducted to examine and analyze the influence of corporate fundamental and macroeconomic factors on the company's stock price LQ45 index on the Indonesia Stock Exchange, the LQ45 index is an index that measures the price performance of 45 stocks that have high liquidity and large market capitalization and is supported by fundamentals good company.

The population studied in this study are all sectors of companies listed on the LQ45 Index, which have gone public and have complete financial statement data from 2013 to 2019. The determination of the sample is done by the Purposive Sampling method, namely the selection of samples based on certain criteria that must be met by sample for analysis. The criteria in the sampling are all companies included in the category of companies that are consistent in the LQ45 Index on the Indonesia Stock Exchange during the period 2013-2019, the company is not included in the banking sector because it has a leverage level from other industrial sectors, companies with financial performance consistent or not experience losses during that period.

Which data analysis technique used is the panel data regression method with the onepanel regression model provides alternatives, common effects, fixed effects, and random effects. It uses the effect model and corrects the effect of the general approach for Ordinary least squares (OLS) in the estimation technique, while the Random Effect uses Generalized Least Squares (GLS).

Panel data regression models using cross-section data and time series, according to Yana Rohmana (2010: 236), are as follows:

$$
Y_{i t}=\propto+\beta 1 X 1_{i t}+E_{i t} ; i=1,2, \ldots, N ; t=1,2, \ldots, T
$$

Yit: Regression coefficient; $N$ : many observations; $\alpha$ : Constant; $\mathrm{T}:$ many time; $\beta$ : $\quad$ Vector NxT : many data pane; Xit : Observation.

\section{RESULTS AND DISCUSSION}

By using E-views software he classic assumption test is a condition for multiple regression to analyze statistics based on ordinary least square (OLS). The classic assumption test aims The regression results meet the Best Linear Unbiased Estimator (BLUE). This research is based on tests Restricted Test (Chow test) and Housman Test, obtained results suitable for use is data pane using the fixed model effect.

Statistical data descriptive is a general description of the object of research that is used as a research sample through the explanation of statistical data is expected to provide an initial picture of the problem under study. 


\section{International Journal of Business Economics (IJBE)}

Vol, 1 Issue 2, pp 117-127, March 2020

http:/ /jurnal.umsu.ac.id/index.php/ijbe

eISSN 2686-472X

Table 1. Descriptive Statistics

\begin{tabular}{lcccccccc}
\hline & $\begin{array}{l}\text { Stock } \\
\text { Prices }\end{array}$ & ROA & ROE & DER & EPS & PER & $\begin{array}{c}\text { Interest } \\
\text { Rate }\end{array}$ \\
\hline Mean & 10004.12 & 0.101672 & 0.202325 & 0.893291 & 542.1393 & 20.69062 & 0.050461 & 0.061547 \\
Median & 4270.000 & 0.086300 & 0.156300 & 0.710000 & 253.2200 & 18.04000 & 0.044200 & 0.065000 \\
Maximum & 85275.00 & 0.466600 & 1.358500 & 5.110000 & 4030.660 & 82.47000 & 0.087900 & 0.077500 \\
Minimum & 196.8050 & 0.015100 & 0.027300 & 0.010000 & 13.54000 & 5.120000 & 0.027900 & 0.042500 \\
Std. Dev. & 14926.16 & 0.080796 & 0.247114 & 0.730251 & 748.6611 & 11.17559 & 0.018604 & 0.012366 \\
Skewness & 2.555557 & 2.392447 & 3.862437 & 2.445928 & 2.545103 & 2.146498 & 0.581181 & -0.213259 \\
Kurtosis & 9.474175 & 9.770861 & 17.10843 & 11.69820 & 9.727228 & 10.60135 & 1.878366 & 1.503359 \\
& & & & & & & & \\
Jarque-Bera & 88469.78 & 89782.72 & 337922.5 & 130075.6 & 92951.41 & 99540.16 & 3329.599 & 3050.424 \\
Probability & 0.000000 & 0.000000 & 0.000000 & 0.000000 & 0.000000 & 0.000000 & 0.000000 & 0.000000 \\
& & & & & & & & \\
Sum & $3.12 \mathrm{E}+08$ & 3187.123 & 6342.282 & 28002.00 & 16994440 & 648588.8 & 1545.477 & 1860.505 \\
Sum Sq. Dev. & $6.95 \mathrm{E}+12$ & 204.6269 & 1914.147 & 16715.78 & $1.76 \mathrm{E}+10$ & 3914923. & 10.59984 & 4.622078 \\
& & & & & & & & \\
Observations & 31207 & 31347 & 31347 & 31347 & 31347 & 31347 & 30627 & 30229 \\
\hline
\end{tabular}

Based on the results of data analysis above the standard deviation is used to measure the spread of data or show the dispersion of various figures. The highest standard deviation value is at stock price 14926.16, which is an EPS of 748.6611, which means that the variable price of shares and EPS has a higher risk of fluctuations compared to other variables. whereas variables that have a low-risk level are ROA, ROE, DER, PER, Inflation and BI Rate variables. which means that these variables tend to be more stable to change during the study period.

Kurtosis is measuring the height of distribution and kurtosis of a normal distribution of data is 3 , if kurtosis exceeds 3 then the data distribution is said to be leptokurtosis to normal, whereas kurtosis is less than 3 then the distribution of data is flat (planktic) compared to normal distribution data. Stock price variables, ROA, ROE, DER, EPS, PER and Exchange rates have a kurtosis value of more than 3 , while the Inflation and BI Rate variables have a kurtosis value of less than 3 .

Jarque-Bera (JB) is a statistical test used to find out whether the data is normally distributed. This test is carried out to measure differences in Skewness and kurtosis of subsequent data compared if the data is normal. with the hypothesis $\mathrm{H} 0$ on normally distributed data, the JB test is distributed with $\mathrm{X}^{2}$ degrees of freedom is 2 . Probability indicates that the probability of JB exceeds (in absolute value) the obsessed value is below the null hypothesis. The statistical test results above show that all variables have a value of more than 0.05 , so it can be said that the data is normally distributed.

\section{Goodness-of-fit test}

Simultaneous significance test or F-statistical test is used to find out how much influence ROA, ROE, DER, EPS, PER, Inflation, and interest rates on the LQ45 Index stock prices from 2013 to 2019 simultaneously or together. In this research, the testing hypothesis used is as follows:

$\mathrm{H} 0=$ Independent variables simultaneously do not affect stock prices.

$\mathrm{Ha}=$ Independent variables simultaneously affect stock prices.

The statistical F test results are 23954.32> 2.241515 f tables, F tables are obtained by finding V1 and V2. V1 $=\mathrm{k}=8, \mathrm{k}=$ number of independent variables, $\mathrm{V} 2=\mathrm{n}-\mathrm{k}-1=30071$ $-8-1=30062$. For the F count of $23954.32>2.241515 \mathrm{f}$ table and the statistical probability 


\section{International Journal of Business Economics (IJBE)}

Vol, 1 Issue 2, pp 117-127, March 2020

http://jurnal.umsu.ac.id/index.php/ijbe

eISSN 2686-472X

value is $0.0000<0.05$ means that ROA, ROE, DER, EPS, PER, Inflation, and interest rates simultaneously have a significant effect on stock prices Stock Index registered on the Indonesia Stock Exchange for the period 2013-2019 at a confidence level of 95.70\%.

The model used in this study is panel data regression, to test the model specificity and the suitability of theories with reality. In this section, we will choose the best panel data regression model. Is it a common effect, fixed effect or random effect. Data processing is done to choose the most appropriate model.

Table 2. Restricted Test (Chow Test)

\begin{tabular}{lrrr}
\hline Effects Test & Statistic & d.f. & Prob. \\
\hline & & & \\
Cross-section F & 2685.382282 & $(20,30043)$ & 0.0000 \\
Cross-section Chi-square & 30830.241152 & 20 & 0.0000 \\
\hline
\end{tabular}

Source: Output E-views

Chow test results in the table above show the value of the cross-section probability $\mathrm{F}=$ $0.0000<0.05$. So $\mathrm{H} 0$ is rejected and $\mathrm{H} 1$ is accepted, meaning that the fixed effect model is more appropriate to use compared to the common effect in estimating panel data.

Table 3. Housman Test

\begin{tabular}{rrrr}
\hline & $\begin{array}{c}\text { Chi-Sq. } \\
\text { Statistic }\end{array}$ & Chi-Sq. d.f & Prob. \\
\hline Test Summary & & & \\
Cross-section random & 92.103665 & 8 & 0.0000 \\
\hline
\end{tabular}

Source: Output E-views

From the results of the Housman test in table above, it can be seen that the probability value is 0.0000 or smaller than alpha 0.05 , meaning that the fixed effect model is better than the random effect.

According to Damodar N. Gujarati (2010) stated several basic choices to determine the fixed effect model with random effects, including if $\mathrm{t}$ (amount of time series data) is greater than $\mathrm{N}$ (number of cross-section units), there might be a slight difference in parameter values estimated by the two models, and the fixed effect model is preferred and more appropriate. And if the individual units (cross-section) of the sample are not random results, the fixedeffect model is more appropriate to be used than the random effect. based on these provisions, the researchers determine or choose the fixed-effect method.

Based on the results of the Chow and Housman Test above, the results show that the right model is the fixed-effect model. The following panel data regression tests using the fixed-effect method in this study are as follows: 


\section{International Journal of Business Economics (IJBE)}

Vol, 1 Issue 2, pp 117-127, March 2020

http://jurnal.umsu.ac.id/index.php/ijbe

eISSN 2686-472X

Table 4. Fixed-effect Model

\begin{tabular}{|c|c|c|c|c|}
\hline Variable & Coefficient & Std. Error & t-Statistic & Prob. \\
\hline ROA & 6433.976 & 1335.706 & 4.816910 & 0.0000 \\
\hline ROE & 5003.039 & 789.3848 & 6.337897 & 0.0000 \\
\hline DER & 625.8536 & 55.21899 & 11.33403 & 0.0000 \\
\hline EPS & 8.463846 & 0.108402 & 78.07861 & 0.0000 \\
\hline PER & 119.2118 & 2.681576 & 44.45585 & 0.0000 \\
\hline Inflation & -17691.20 & 1441.513 & -12.27266 & 0.0000 \\
\hline Interest Rate & -36803.10 & 1913.226 & -19.23615 & 0.0000 \\
\hline $\mathrm{C}$ & 1971.477 & 306.1516 & 6.439544 & 0.0000 \\
\hline \multicolumn{5}{|c|}{ Effects Specification } \\
\hline \multicolumn{5}{|c|}{ Cross-section fixed (dummy variables) } \\
\hline R-squared & 0.957128 & \multicolumn{2}{|c|}{ Mean dependent var } & 9965.464 \\
\hline Adjusted R-squared & 0.957088 & \multicolumn{2}{|c|}{ S.D. dependent var } & 14827.05 \\
\hline S.E. of regression & 3071.446 & \multicolumn{2}{|c|}{ Akaike info criterion } & 18.89865 \\
\hline Sum squared resid & $2.83 \mathrm{E}+11$ & \multicolumn{2}{|c|}{ Schwarz criterion } & 18.90666 \\
\hline Log likelihood & -284131.1 & \multicolumn{2}{|c|}{ Hannan-Quinn criter. } & 18.90122 \\
\hline F-statistic & 23954.32 & \multicolumn{2}{|c|}{ Durbin-Watson stat } & 0.014081 \\
\hline Prob(F-statistic) & 0.000000 & & & \\
\hline
\end{tabular}

Source: Output E-views

\section{Discussion}

\section{Effect of Return On Assets (ROA) on Stock Prices}

Return On Assets (ROA) is one indicator of profitability ratios that are used to measure a company's ability to generate profits with assets owned. This ratio sees the extent to which investments that have been invested can provide a return on profits as expected. The results of the data analysis of the probability value of the effect of the Return On Asset (ROA) variable on stock prices are 0.0000 with a regression coefficient with a positive value. because the significance value obtained $0.0000<0.05$ and the positive regression coefficient, $\mathrm{H} 0$ is rejected and Ha is accepted, it is concluded that Return On Assets (ROA) has a positive effect on stock prices. which means the greater ROA will increase the stock price and vice versa.

This result is in line with previous research conducted by Okinawa Safitri \& Aminar Sutra Dewi (2019) which states the Return On Asset variable has a positive effect on stock prices. but different from the results of research conducted by M. Mabrur Alifiawan, et al (2017). which states Return On Assets has no significant positive effect on stock prices on LQ45 Index companies.

\section{Effect of Return On Equity (ROE) on Stock Prices}

Return On Equity (ROE) is one indicator of profitability ratios that are used to measure a company's ability to generate profits with assets owned. The results of the data analysis of the probability value of the influence of the variable Return On Equity (ROE) on the stock price is 0.0000 with a regression coefficient with a positive value. because the significance value obtained $0.0000<0.05$ and the positive regression coefficient, $\mathrm{H} 0$ is rejected and $\mathrm{Ha}$ is 


\section{International Journal of Business Economics (IJBE)}

Vol, 1 Issue 2, pp 117-127, March 2020

http://jurnal.umsu.ac.id/index.php/ijbe

eISSN 2686-472X

accepted, it is concluded that Return On Equity (ROE) has a positive effect on stock prices. which means the greater the Return On Equity (ROE) will increase the stock price, and vice versa.

These results are in line with previous research conducted by Gadang Gagas \& Darminto (2013) and Ari Krisnianti Sinaga et al. (2014) which states the Return On Equity variable has a positive effect on stock prices. but different from the results of research conducted by Amanda WBBA \& Wahyu Ario Pratomo (2013) which states Return On Assets has no significant effect on stock prices on LQ45 Index companies.

\section{Effect of Debt to Equity Ratio (DER) on Stock Prices}

The results of the data analysis of the probability value of the influence of the variable Debt to Equity Ratio (DER) on the stock price is 0.0000 with a regression coefficient with a positive value. because the significance value obtained $0.0000<0.05$ and the positive regression coefficient, $\mathrm{HO}$ is rejected and $\mathrm{Ha}$ is accepted, it is concluded that Debt to Equity Ratio (DER) has a positive effect on stock prices. which means the greater the Debt to Equity Ratio (DER), it will increase the price of the stock and vice versa.

This result is in line with the capital structure theory that if a company can manage its debt structure well, then debt can become a leverage factor that can ultimately increase EPS. If a company can increase its function greater than the costs incurred by debt, then debt can be made an alternative or choice by the company to be able to expand and develop the business. If the company makes good use of debt, the company will bear interest costs. This interest cost can be a tax deduction factor so that the profit received is greater. This will get a positive response from potential investors. As long as the company has no problems in returning debt, this will only increase the level of investor confidence to invest in the company's shares.

\section{Effect of Earning per Share (EPS) on Stock Prices}

The results of the data analysis of the probability value of the effect of Earning per Share (EPS) variable on stock prices are 0.0000 with a regression coefficient with a positive value. because the significance value obtained $0.0000<0.05$ and the positive regression coefficient, $\mathrm{HO}$ is rejected and $\mathrm{Ha}$ is accepted, it is concluded that Earnings per share (EPS) has a positive effect on stock prices. which means the greater Earnings per Share (EPS) can increase stock prices, and vice versa.

Earnings per Share becomes a reference for potential investors to buy shares and becomes one of the variables to analyze how much profit by prospective buyers of shares in determining the purchase of certain shares.

These results are no different in line with the results of research conducted by Okinawa Safitri \& Aminar Sutra Dewi (2019) and Alif Mohamad Khalifah \& Farida point (2015) states that Earnings per Share (EPS) has a positive and significant effect on stock prices.

\section{Effect of Price Earnings Ratio (PER) on Stock Prices}

The results of data analysis show that the probability value of the effect of the Price Earning Ratio (PER) on stock prices is 0.0000 with a regression coefficient with a positive value. because the significance value obtained $0.0000>0.05$ and the negative regression coefficient, $\mathrm{HO}$ is rejected and $\mathrm{Ha}$ is accepted, it is concluded that Price Earning Ratio (PER) has a significant effect on stock prices. 


\section{International Journal of Business Economics (IJBE)}

Vol, 1 Issue 2, pp 117-127, March 2020

http://jurnal.umsu.ac.id/index.php/ijbe

eISSN 2686-472X

The results of this study are the same and in line with the results of research conducted by Amanda WBBA \& Wahyu Ario Pratomo (2013) states that Price Earning Ratio (PER) has a significant positive effect on stock prices. but different results by Gadang Gagas \& Darminto (2013) stated that the Price Earnings Ratio (PER) had no significant effect on stock prices.

\section{Effect of Inflation on Stock Price}

The results of data analysis show that the probability of the effect of inflation on stock prices is 0.0000 with a regression coefficient with a negative value. because the significance value obtained $0.0000<0.05$ with a negative regression coefficient, $\mathrm{H} 0$ is rejected and $\mathrm{Ha}$ is accepted, it is concluded that inflation has a negative and significant impact on stock prices on the LQ45 index company.

Inflation has a negative and significant effect on stock prices. The results of this study are in line with the results of research I Gusti Ayu Purnamawati \& Desak Nyoman (2013), and in line with Alamsjah (2017), this shows that inflation has a negative influence on stock prices. A general and overall price increase will result in a decrease in consumer purchasing power. High and low inflation can affect the ups and downs of stock prices.

\section{Effect of Interest Rates on Stock Prices}

The results of data analysis show that the probability value of the effect of the Interest Rate on stock prices is 0.0000 with a regression coefficient with a negative value. because the significance value obtained is $0.0000<0.05$ and the regression coefficient is negative then Ho is rejected and $\mathrm{Ha}$ is accepted, it can be concluded that the BI-Rate has a negative and significant effect on stock prices.

Interest rates will influence investors' decisions to invest in shares. High and lowinterest rates affect the stock returns to be received by investors. Interest rates have a negative and significant effect on stock prices. These results are in line with the results of Jana Simakovov, et al (2019), and in line with I Gusti Ayu Purnamawati \& Desak Nyoman (2013) which states that interest rates have a negative effect on stock prices on LQ45 index companies.

\section{Implications}

Companies can update information related to companies especially finance, making information easily understood by potential investors. The company improves good governance in the financial budget to remain stable and consistent in the LQ45 Index category. The company is improving improvements in its financial system to be more efficient in implementing its capital structure.

The stock price is a good reflection of the company's finances, which are updated with stable and continuously rising stock prices on the capital market. For investors, it is more necessary to deepen the analysis of corporate and technical fundamentals in making investment decisions by also taking into account external or macroeconomic factors that affect stock prices.

\section{CONCLUSION}

The results of this study indicate that company fundamentals and macroeconomic factors can affect stock prices, where stock prices are influenced by investors' decisions in deciding to buy shares. Return on Assets and Return On Equity are profitability ratios which 


\section{International Journal of Business Economics (IJBE)}

Vol, 1 Issue 2, pp 117-127, March 2020

http:/ /jurnal.umsu.ac.id/index.php/ijbe

eISSN 2686-472X

are fundamental in measuring and assessing the rate of return on invested capital and assets. The results of data analysis show that positively affect stock prices. These results are in line with the hypothesis that has a positive and significant effect on stock prices. Debt to Equity Ratio is a leverage ratio or lever factor in supporting capital and financing operational activities. Thomas E Copeland (1996) also suggests a capital structure theory in which corporate financing usually uses more debt than equity capital for financing, debt is also used as a tax deduction factor, the optimal capital structure must reach a balance that is between risk and return to maximize stock price. Earning Per Share is a market ratio in analyzing the rate of return per share, usually investors analThe results of this study indicate that company fundamentals and macroeconomic factors can affect stock prices, where stock prices are influenced by investors' decisions in deciding to buy shares. Price Earning Ratio (PER) that is too high reflects the stock price that is overvalued or overpriced. In this case, the market places too high an expectation on the profit or return that the stock will obtain in the future. As a result the stock price becomes more expensive than the fair price.

Inflation has a negative influence on stock prices. A general and overall price increase will result in a decrease in consumer purchasing power. High and low inflation can affect the ups and downs of stock prices Inflation affects stock prices negatively and significantly, this result is in line with the hypothesis which states that inflation has a negative and significant effect on stock prices. Interest rates will influence investors' decisions to invest in shares. High and low interest rates affect the stock returns that will be received by investors. interest rates affect stock prices negatively and significantly, this result is in line with the hypothesis that interest rates have a negative and significant effect on stock prices. Taken together fundamental factors and macroeconomic factors influence stock prices significantly. These results are in line with the hypothesis which states that fundamental factors and macroeconomic factors influence and significantly affect stock prices.yze EPS to assess the company's profit and prospects in the future. the result of data analysis states that EPS affects stock prices positively and significantly, this result is in line with the hypothesis which states that Earning per Share has a positive and significant effect on stock prices.

\section{REFERENCES}

BI Rate Reverse 7-Days Repo Rate . (2019, September). Retrieved September 2019, 2019, from Bank Indonesia: http://www.bi.go.id

Data Inflasi Indeks Harga Konsumen . (2019, September). Retrieved September 21, 2019, from Badan Pusat Statistik: http://www.bps.go.id/Inflasi

Performa Saham Indeks LQ45. (2019, September). Retrieved September 21, 2019, from Indonesian Stock Exchange : http://www.idx.co.id

Stock Performance. (2019, September 21). Retrieved September 21, 2019, from Investing.com: http://www.Investing.com/Stock

Agus Tri Basuki, P. N. (2017). Analisis Regresi Dalam Penelitian Ekonomi \& Bisnis : Dilengkapi Aplikasi SPSS \& EVIEWS. Depok: PT Rajagrafindo Persada.

Alamsjah. (Juni 2017). Jurnal Ekonomix Voulme 5 Nomor 1. Pengaruh Faktor Makro Ekonomi Terhadap Harga Saham Industri Makanan Yang tercatat di Bursa Efek Jakarta.

Bargava, A. (2014). Journal of Econometrics. Firm's Fundamentals, macro economics variables and quarterly stock prices in the U.S.

Brigham, J. F. (2006). Dasar-Dasar Manajemen Keuangan. Jakarta : Salemba Empat.

Darmadji, F. (2012). Pasar Modal di Indonesia, Edisi Ketiga. Jakarta: Salemba Empat. 


\section{International Journal of Business Economics (IJBE)}

Vol, 1 Issue 2, pp 117-127, March 2020

http:/ /jurnal.umsu.ac.id/index.php/ijbe

eISSN 2686-472X

Fahmi, I. (2012). Analisis Kinerja Keuangan, Panduan bagi Akademisi, Manager, dan Investor Menilai dan Menganalisis Bisnis dari Aspek Keuangan. Bandung: Alfabeta.

Fakhruddin, S. H. (2001). Perangkat dan Model Analisis Investasi di Pasar Modal Buku Satu. Jakarta: Elex Media Komputindo.

Gadang Ganggas Rakasetya, D. M. (Desember 2013). Jurnal Administrasi Bisnis (JAB) | Vol. 6 No. 2 . Pengaruh Faktor Mikro dan Faktor Makro Ekonomi Terhadap Harga Saham Perusahaan Mining and Mining Services yang terdaftar di Bursa Efek Indonesia (BEI) Periode 2008-2011.

Ghozali, I. (2012). Aplikasi Analisis Multivariate dengan Program IBM SPSS. Yogyakarta: Universitas Diponegoro.

Gudono. (2016). Analisis data multivariat (edisi ketiga). Yoyakarta: BPEE.

Husnan, P. (2006). Dasar-Dasar Manajemen Keuangan. Edisi Ketiga. Yogyakarta: UPP STIM YKPN.

Kasmir. (2008). Analisis Laporan Keuangan, Edisi Kesebelas. Jakarta: PT Raja Grafindo Persada.

Madura, J. (2002). Financial Institution and Markets 6th Edition. South Westen : Division Of Thompson Learning .

Mukhammad Mabrur Alifiawan, A. M. (2019). Jurnal Tata Sejuta Vol. 5, No.1 P-ISSN 24429023, E-ISSN 2615-0670. . Pengaruh Fundamental dan Makro Ekonomi Terhadap Harga Saham Perusahaan Multinasional (Studi Kasus Perusahaan Industri Dasar dan Kimia Tahun 2016 - 2017).

Okinawa Syahfitri, A. S. (n.d.). https://osf.io/preprints/9p2h6/. Pengaruh Kondisi Fundamental, Inflasi dan Suku Bunga Sertifikat Bank Indonesia Terhadap Harga Saham (Studi Kasus Perusahaan Real Estate dan Property yang terdaftar di Bursa Efek Indonesia).

Purwanto. (2006). Ekonomi SMA X. Jakarta : Tunas Melati.

R., H. P. (2012). Jurnal Nominal Voume I (1). Pengaruh Dividend Per Share, Return On Equity Dan Net Profit Margin Terhadap Harga Saham Peruwsahaan Industri Manufaktur Yang Tercatat Di Bursa Efek Indonesia Periode 2006-2010, 104-123.

Ratih, D. A. (2013). Journal of Social and Politic. pp . Pengaruh EPS, PER, DER, ROE Terhadap Harga Saham pada Perusahaan Pertambangan yang Terdaftar di Bursa Efek Indnesia (BEI) Tahun 2010-2012, 1-12.

Saripudin, H. L. (Agustus 2017). Jurnal Bisnis dan Komunikasi KalbiSocio Vol. 4 No 2. Pengaruh Makro Ekonomi Terhadap Harga Saham Pada Perusahaan Sektor Perbankan di Bursa Efek Indonesia.

Sarono, D. Y. (2014). Pengaruh Inflasi, Tingkat Suku Bunga SBI Dan Nilai Tukar Dollar Terhadap Harga Saham Preperti Yang Terdaftar Dalam LQ45 Di Bursa Efek Indonesia, 1-17.

Sartono, A. (2010). Manajemen Keuangan Teori dan Aplikasi. Yogyakarta: BPFE.

Sedarmayanti, S. H. (2011). Metodologi Penelitian. Bandung: Mandar Maju.

Siregar, S. (2010). Statistika Deskriptif Untuk Penelitian. Jakarta: PT Rajagrafindo Persada.

Sudana, I. M. (2011). Manajemen Keuangan Perusahaan. Jakarta : Erlangga.

Sugiyono. (2017). Metode Penelitian Kuantitatif, Kualitatif dan R\&D. Bandung: Alfabeta, CV.

Sunariyah. (2006). Pengantar Pengetahuan Pasar Modal . Yogyakarta: UPP STIM YKPN. 


\section{International Journal of Business Economics (IJBE)}

Vol, 1 Issue 2, pp 117-127, March 2020

http://jurnal.umsu.ac.id/index.php/ijbe

eISSN 2686-472X

Umar Gunu, I. O. (2009). An International Multi-Disciplinary Journal, Eutophia. Environmental Factors Influencing Fluctuation of Share Prices on Nigeria Stock Exchange Market.

Wardani, D. K., \& Andarini, D. F. (2016). Jurnal Akuntansi, [S.1.], v. 4, n. 2, p. ISSN 25409646. Pengaruh Kondisi Fundamental, Inflasi, dan Suku Bunga Sertifikat Bank Indonesia Terhadap Harga Saham (Study Kasus pada Perusahaan Real Estate dan Property yang terdaftar di Bursa Efek Indonesia tahun 2010-2013), 77 - 90.

Winarno, W. (2015). Analisis Ekonometrika dan Statistika dengan E-Views Edisi 4. Yogyakarta: UPP STIM YKPN. 